\title{
Efficacy of an Eco-Friendly Bloom Thinning Formulation on Mango Trees and Its Olfactory Effect on an Insect Pollinator, Apis mellifera
}

\author{
Tae-Kwon Son ${ }^{1}$, Md Munir Mostafiz ${ }^{2}$ D, Hwal-Su Hwang ${ }^{2}$, Nguyen Truong Thạnh ${ }^{3}$ and Kyeong-Yeoll Lee ${ }^{2,4}, *(\mathbb{D}$ \\ 1 Department of Farm Management, College of Agriculture and Life Sciences, Kyungpook National University, \\ 80, Daehak ro, Buk-gu, Daegu 41566, Korea; apple@applebio.info \\ 2 School of Applied Biosciences, College of Agriculture and Life Sciences, Kyungpook National University, \\ 80, Daehak ro, Buk-gu, Daegu 41566, Korea; munirmostafiz12@gmail.com (M.M.M.); \\ bgtwo2@naver.com (H.-S.H.) \\ 3 Plant Protection Research Institute, Vietnam Enasa JSC, No. 26, Chung cu 8X PLUS, P. Tan Thoi Nhat, \\ Q 12, Hochiminh 729930, Vietnam; ntthanh.enasa@gmail.com \\ 4 Institute of Agricultural Science and Technology, Kyungpook National University, 80, Daehak ro, Buk-gu, \\ Daegu 41566, Korea \\ * Correspondence: leeky@knu.ac.kr; Tel.: +82-53-950-5759
}

Citation: Son, T.-K.; Mostafiz, M.M.; Hwang, H.-S.; Thanh, N.T.; Lee, K.-Y. Efficacy of an Eco-Friendly Bloom Thinning Formulation on Mango Trees and Its Olfactory Effect on an Insect Pollinator, Apis mellifera. Horticulturae 2021, 7, 62. https:// doi.org/10.3390/horticulturae7040062

Academic Editor: Esmaeil Fallahi

Received: 12 February 2021

Accepted: 22 March 2021

Published: 24 March 2021

Publisher's Note: MDPI stays neutral with regard to jurisdictional claims in published maps and institutional affiliations.

Copyright: (c) 2021 by the authors. Licensee MDPI, Basel, Switzerland. This article is an open access article distributed under the terms and conditions of the Creative Commons Attribution (CC BY) license (https:// creativecommons.org/licenses/by/ $4.0 /)$.

\begin{abstract}
In various orchard fruit trees, thinning of blossoms and fruits is important to increase fruit size and quality and to promote a new bloom in the following season. Several chemical thinning agents are currently commercially available, but they are inconsistent and produce side effects in crop plants and insect pollinators. Because of environmental concerns, developing alternative eco-friendly bloom thinning agents is necessary. We developed an eco-friendly bloom thinning formulation (BTF) using minerals and extracts of various medicinal plants. Our BTF spray $(0.1 \%, w / v)$ decreased the number of fruits per tree $(46.5 \%)$ and fruit yield per tree $(81.5 \%)$ but increased the fruit weight (196.8\%) compared with the control treatment; the spray induced a small number of larger mango fruits in the treated trees. We also investigated the effect of BTF on the olfactory behavior of Apis mellifera L. (Hymenoptera, Apidae), a major insect pollinator. We analyzed the behavioral changes of adult workers at two different concentrations $(0.1 \%$ and $1 \%)$ of nine different BTF spray components using a Y-tube olfactometer. The behavioral responses of honey bees to nine BTF components showed significant differences. However, honey bees showed no clear attraction or repellent behavior towards the tested BTF components. Our results suggest that the newly developed eco-friendly BTF is practically applicable in mango orchards without interrupting honey bee behavior.
\end{abstract}

Keywords: fruit trees; mango; orchard management; insect pollinator; thinning agents

\section{Introduction}

When fruit trees produce more flowers and fruits, the size and quality of fruit are reduced. Hence, thinning is necessary to reduce crop load and increase the market value of tree crops [1-4]. Thinning promotes bloom again in the following season in some orchard trees, such as apples and plums [4,5]. Thinning methods have been developed using hand, mechanical, and chemical methods [1,5]. Hand thinning is the most timeconsuming method and is unprofitable because of the labor intensity and prolonged time [1]. By contrast, mechanical thinning using rope, club, or high-pressure spray guns can be used; however, these methods easily bruise and damage fruits, making them commercially unacceptable [1]. Using a hand-held electrical device can be useful for the post-bloom mechanical thinning of peach trees [6].

The chemical thinning method is more economical compared with the hand or mechanical thinning methods [7]. Several chemical thinning agents (i.e., ethephon, ammonium 
thiosulphate, naphthyl acetic acid, carbaryl, benzyladenine, naphthalene acetic acid conjugates, and gibberellins) are currently available in the market [8-13]. In addition, minerals, such as lime sulfur, are commercially available as thinning agents [14]. However, the major problem of most chemical thinning agents is inconsistent thinning effect due to different environmental conditions of orchard trees [7]. Furthermore, some agents are toxic to plants and pollination insects $[14,15]$.

Bloom thinning coincides with the pollination activity season of insects, such as bees, beetles, moths, and flies. There is a concern regarding the effect of thinning agents on the behavior and physiology of insect pollinators because some chemical thinning agents are harmful to insect pollinators. For example, carbaryl (1-naphthyl-N-methylcarbamate) has a fruit thinning activity on apple trees [16,17]; however, this compound is a highly toxic pesticide, and its use was reduced because of harmful effects on insect pollinators and related environmental concerns [1]. Therefore, it is important to develop eco-friendly thinning agents that are safe for insect pollinators, ecosystems, and organic farmers. Ecofriendly thinning formulations have been recently developed using minerals and various organic compounds extracted from plants [18-20].

Mango, Mangifera indica L. (Anacardiaceae), is one of the most important tropical fruits and is favored worldwide for its particular flavor and high nutritional value [21]. During the harvest season, the mango fruit size is important in determining the market price [22]. Therefore, blooming and fruit thinning is necessary to produce economically profitable mango fruits [22]. However, studies on the efficacy of applying thinning agents for the mango tree are limited $[23,24]$.

This study aimed to determine the thinning efficacy of a newly developed bloom thinning formulation (BTF) in mango orchards in Vietnam. Moreover, the study investigated whether each component of the developed BTF induces an olfactory response and changes the behavior of an insect pollinator, the Western honey bee Apis mellifera L. (Hymenoptera, Apidae). For this experiment, we used a Y-tube olfactometer bioassay commonly used for determining the behavioral response of insects to volatile organic compounds [25].

\section{Materials and Methods}

\subsection{BTF}

BTF (Apple Co. Ltd., Daegu, Korea) was formulated using the mineral ingredients and extracts of various medicinal plants (Table 1).

Table 1. Major components of the bloom thinning formulation.

\begin{tabular}{lcc}
\hline \multicolumn{1}{c}{$\begin{array}{c}\text { Components of the Bloom } \\
\text { Thinning Formulation }\end{array}$} & $\begin{array}{c}\text { Proportions (\%) in the } \\
\text { Bloom Thinning } \\
\text { Formulation }\end{array}$ & Main Active Ingredients \\
\hline 1. Extract of seaweed & $<18$ & Alginate \\
2. Nitrogen, zinc, boron & $<46$ & Nitrogen \\
3. Extract of low quality fresh & $<2$ & Ginsenoside \\
Panax ginseng & $>1$ & Limonene \\
4. Extract of $>$ Chenopodium & $<20$ & Essential oil \\
ambrosioides & $<10$ & Saponin \\
5. Extract of Houttuynia cordata & $>1$ & Organic acid \\
6. Extract of Bupleurum & - & Water \\
falcatum & & \\
7. Wood vinegar &
\end{tabular}

\subsection{BTF Treatment on a Mango Orchard}

We conducted field trials in a mango orchard $\left(10^{\circ} 40^{\prime} 88.0^{\prime \prime} \mathrm{N}, 105^{\circ} 70^{\prime} 78.0^{\prime \prime} \mathrm{E}\right)$ located in Dong Thap Province, Mekong River Delta in Vietnam; we used five-year-old mango trees (Taiwan native strain) for the study. Mango trees began blooming in late February. We sprayed BTF twice: First at the completion of $80-90 \%$ of the blooming season in 
early March and then during the full-bloom season in the middle of March. We diluted BTF to a concentration of $0.1 \%$ with water and sprayed an amount of $25 \mathrm{~L}$ on each tree, which averaged $10 \mathrm{~m}$ in height. We treated control trees with the same amount of water as the mango trees. The field experiment was performed in a randomized complete block design with three replications (five trees in each block). At 150 days post-treatment, we harvested mango fruits from the BTF-treated $(n=15)$ and untreated trees $(n=15)$ and counted the average number of fruits per tree. In addition, we obtained the average weight of fruits per tree, and measured the average yield per tree by counting the number of total fruits per tree.

\subsection{Honey Bees}

We obtained $A$. mellifera worker bees (<10 days old) from an apiculture farmer in Chilgok, Korea and placed them in an acrylic cage $(38 \times 38 \times 34 \mathrm{~cm})$ at the Insect Physiology Laboratory, Kyungpook National University, Korea. The caged bees were provided with two insect breeding containers $(100 \mathrm{~mL})$ containing 50\% $(w / v)$ sucrose solution-soaked cotton balls as a temporal food source. We maintained the cage under the following conditions: A temperature of $25 \pm 2{ }^{\circ} \mathrm{C}$, relative humidity of $60 \% \pm 10 \%$, and photoperiod of 12-h light:12-h dark.

\subsection{Olfactory Responses of A. mellifera to BTFs}

We used a Y-tube olfactometer (Figure 1) for evaluating the olfactory responses of $A$. mellifera as per the Mostafiz et al. [25] method. We diluted the BTF components with water to achieve the desired concentrations of $0.1 \%$ and $1 \%$. Next, we added an aliquot $(60 \mu \mathrm{L})$ of each concentration to a polyethylene vial $(1 \mathrm{~mL})$ and added it in one of two bottles. The second bottle contained the same amount of distilled water. We passed medical grade compressed air through the tubes at a rate of $300 \mathrm{~mL} / \mathrm{min} / \mathrm{arm}$ using flowmeters.

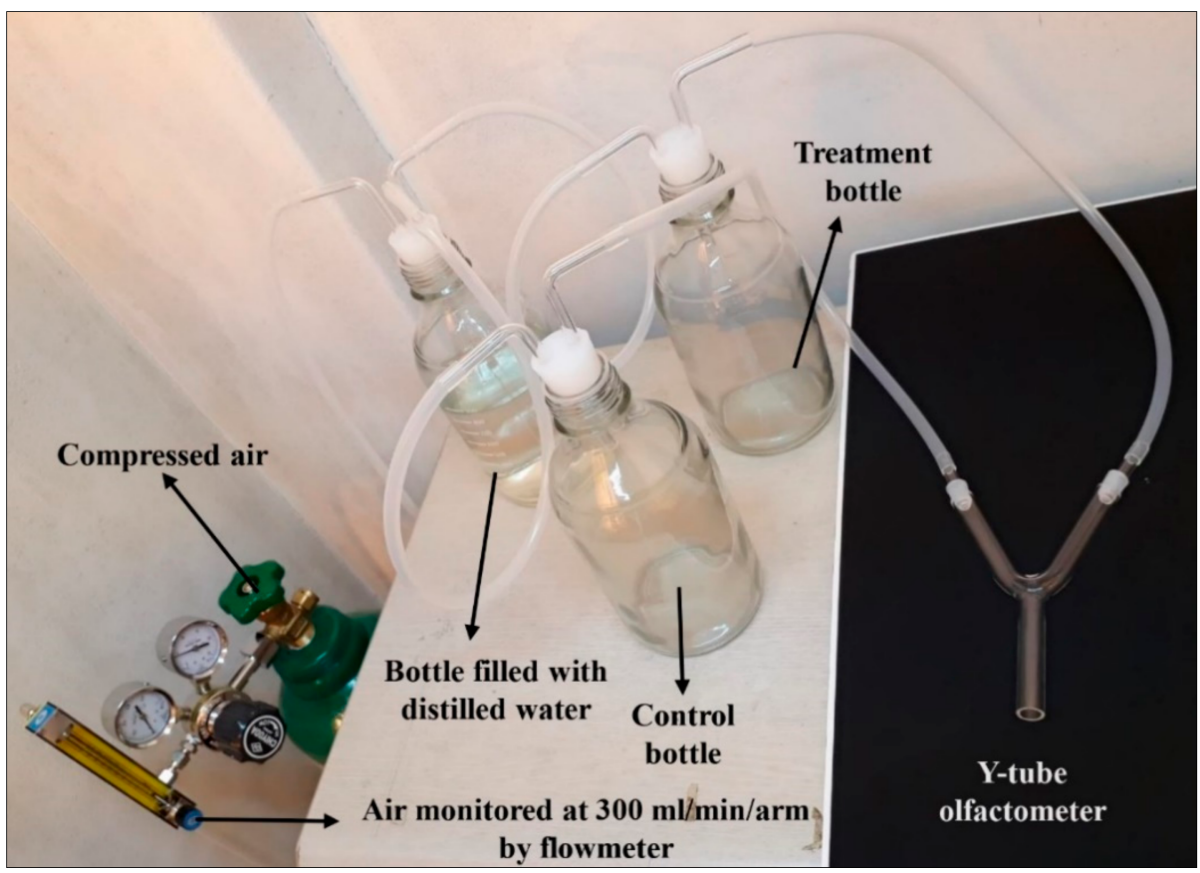

Figure 1. The Y-tube olfactometer apparatus used to investigate the olfactory responses of the honey bees for each component of the bloom thinning formulation.

Before the bioassay, we starved adult worker bees ( $<10$ days old) for $2 \mathrm{~h}$ to promote rapid response to treated compounds. After initiating airflow, we inserted one worker bee into the Y-tube at a time. When the adult worker crossed the odor-source branch or control branch by more than a third of the length, we presumed that the bee made a choice. The bees 
that stayed in the main stem for 10 min were marked as unresponsive. We tested the relative position of the tested stimulus and alternated the corresponding control between replicates to avoid any spatial bias in the bees' behavior. For each test, a clean Y-tube was used to prevent odor transfer. A total of 10 replications for individual BTF was performed. The Y-tube was illuminated with a red light to avoid using visual signals during the experiments. We performed all bioassays between 10:00 a.m. and 5:00 p.m. in a room maintained at a temperature of $25 \pm 2{ }^{\circ} \mathrm{C}$ and a relative humidity of $60 \% \pm 10 \%$. The Ytubes were thoroughly washed with acetone and distilled water after each test before air drying. The response rate (\%) of test samples on A. mellifera in the Y-tube olfactometer was calculated using a formula reported by Li et al. [26].

$$
\text { Response rate }(\%)=(\text { Responding bees } / \text { Total tested bees }) \times 100
$$

\subsection{Statistical Analysis}

For this study, we performed an $F$-test for comparing the average fruit number and weight between the control and BTF-treated trees after 150 days post-treatment (harvest), respectively. Moreover, we performed a Fisher's exact test to determine any nonrandom associations between the number of bees that selected the olfactometer's treatment or control arm. This analysis was performed using PROC FREQ in SAS 9.4. Furthermore, a paired $t$-test was used to compare the time spent by the bees in each arm. All data were analyzed using SAS 9.4 software (SAS Institute, Cary, NC, USA, 2016) [27], and we used Sigma plot 12.5 (Systat Software Inc., San Jose, CA, USA, 2013) to draw all graphs.

\section{Results}

\subsection{Effects of BTF Treatment on Mango Trees}

The number and weight of mango fruits were compared between BTF-treated and untreated control trees (Figure 2).
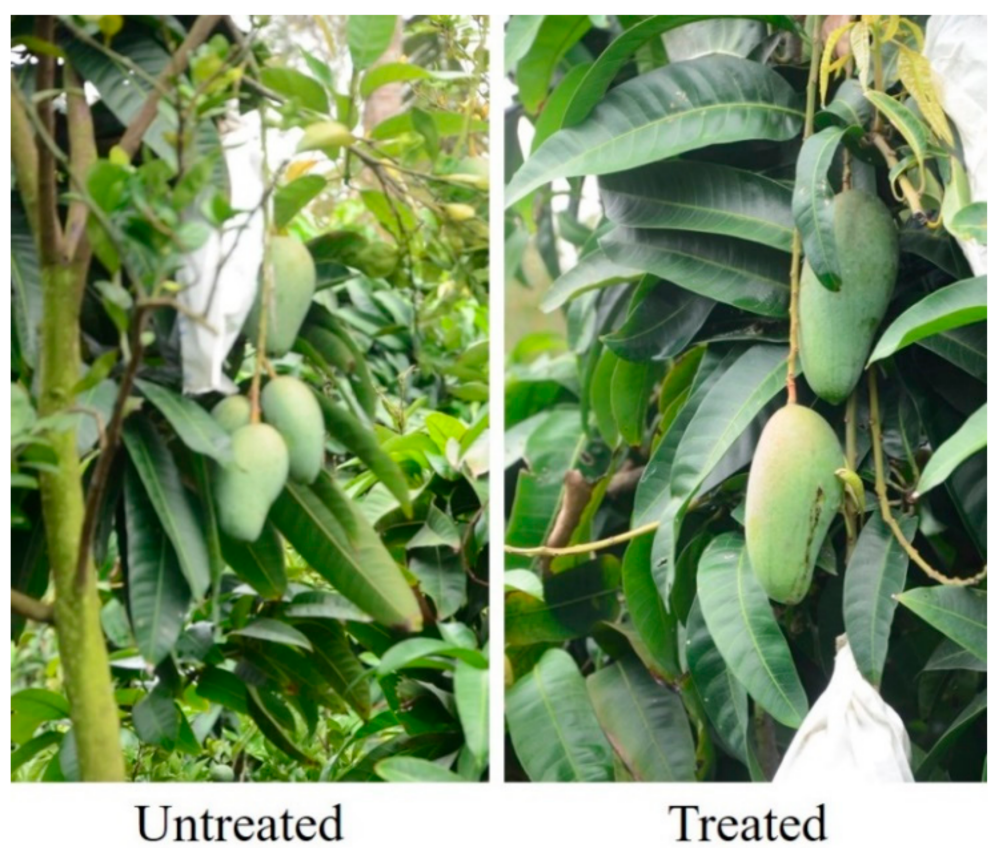

Figure 2. Effect of spraying bloom thinning formulation (BTF) on mango trees. BTF solution (0.1\%) was sprayed two times: First at the completion of $80-90 \%$ of the blooming season and second during the full-bloom season on 5-year-old mango trees $(n=15)$ of the Taiwan strain.

At the harvest season (150 days post-treatment), the average fruit number per tree was reduced to $46.3 \%$ compared with the control; however, fruit weight was increased to $196.8 \%$ compared with the control. The average yield of the treated trees was reduced to 
$81.5 \%$ compared with the control trees (Table 2). The BTF spray induced a small number of fruits per tree and reduced the overall yield but produced nearly two times larger fruits on the mango trees.

Table 2. Effects of organic bloom thinning formulation on mango trees.

\begin{tabular}{ccccccc}
\hline Treatment & $\begin{array}{c}\text { Number of } \\
\text { Mango Trees } \\
\mathbf{( N )}\end{array}$ & $\begin{array}{c}\text { Average } \\
\text { Number Fruits } \\
\text { per Tree }\end{array}$ & $\begin{array}{c}\text { Average } \\
\text { Weight } \\
\mathbf{( k g / f r u i t )}\end{array}$ & $\begin{array}{c}\text { Average Yield } \\
\text { (kg/tree) }\end{array}$ & $\begin{array}{c}\text { Price (1000 } \\
\text { VND/kg) }\end{array}$ & $\begin{array}{c}\text { Total Revenue } \\
\mathbf{( 1 0 0 0} \\
\text { VND/tree) }\end{array}$ \\
\hline $\begin{array}{c}\text { Control-treated } \\
\text { orchard }\end{array}$ & 15 & $55.3^{\mathrm{b}} \pm 2.2$ & $0.635^{\mathrm{a}} \pm 0.06$ & $35.1^{\mathrm{b}} \pm 1.7$ & 10 & 351 \\
$\begin{array}{c}\text { Bloom thinning } \\
\text { formulation- } \\
\text { treated } \\
\text { orchard }\end{array}$ & 15 & $25.6^{\mathrm{a}} \pm 1.4$ & $1.250^{\mathrm{b}} \pm 0.06$ & $28.6^{\mathrm{a}} \pm 1.6$ & 32 & 772 \\
\hline
\end{tabular}

Means within a column not sharing a common letter are significantly different at $\alpha=0.05$ using $F$-test.

We also compared the price of mango fruits in Vietnam markets between fruits harvested from BTF-treated trees and untreated ones. The mango fruits harvested from BTF-treated trees commanded a 320\% higher market price than those from the control trees. Moreover, the total revenue of BTF-treated mango fruits was $220.1 \%$ higher than that of the control (Table 2).

\subsection{Olfactory Responses of A. mellifera to BTF Components}

In the olfactory experiment, $>85 \%$ of the worker bees approached either the BTF components or the control within the maximum time allowed (10 min). However, there were no significant differences between the time spent by worker bees in the Y-tube olfactometer in the treatment and control arms; the bees spent almost similar times in both arms (Table 3).

Table 3. The average time spent by Apis mellifera worker bees in a Y-tube olfactometer with each component of bloom thinning formulations at $1 \%$ concentration.

\begin{tabular}{|c|c|c|c|c|c|}
\hline \multirow{2}{*}{$\begin{array}{l}\text { Bloom Thinning } \\
\text { Formulation Component }\end{array}$} & \multirow{2}{*}{$\mathbf{N}^{\mathrm{a}}$} & \multicolumn{4}{|c|}{ Number of Minutes Spent in the Arm (Mean \pm SD) } \\
\hline & & Treatment & Control & $t$-Value & $p$-Value \\
\hline Extract of seaweed & $10(9)$ & $6.02(1.16)$ & $6.32(0.95)$ & 0.49 & 0.6561 \\
\hline Nitrogen, zinc, boron & $10(8)$ & $5.62(0.43)$ & $6.54(1.29)$ & 1.73 & 0.1824 \\
\hline $\begin{array}{l}\text { Extract of low quality } \\
\text { fresh Panax ginseng }\end{array}$ & $10(10)$ & $7.08(1.41)$ & $7.24(1.08)$ & 0.39 & 0.7185 \\
\hline $\begin{array}{c}\text { Extract of }>\text { Chenopodium } \\
\text { ambrosioides }\end{array}$ & $10(9)$ & $6.23(1.44)$ & $7.64(1.13)$ & 0.98 & 0.3995 \\
\hline $\begin{array}{l}\text { Extract of Houttuynia } \\
\text { cordata }\end{array}$ & $10(9)$ & $7.05(1.15)$ & $6.68(1.71)$ & -0.39 & 0.7235 \\
\hline $\begin{array}{l}\text { Extract of Bupleurum } \\
\text { falcatum }\end{array}$ & $10(9)$ & $6.32(0.89)$ & $6.88(1.75)$ & 1.38 & 0.2603 \\
\hline Wood vinegar & $10(10)$ & $5.92(1.17)$ & $6.55(1.17)$ & 0.75 & 0.4957 \\
\hline Inert ingredient & $10(9)$ & $6.00(1.18)$ & $6.97(1.30)$ & 2.7 & 0.0741 \\
\hline
\end{tabular}

${ }^{a}$ Total sample size ( $\mathrm{N}$, in the main stem of the olfactometer, the number of individuals that respond within 10 min is shown in parentheses).

A paired sample $t$-test was used to analyze differences between the time spent by Apis mellifera in each arm.

The behavioral responses of honey bees to nine BTF components showed significant differences. However, the Y-tube olfactometer experimental findings showed that none of the BTF components had strong attractant or repellent effect on the honey bees (Figures 3 and 4 ). 


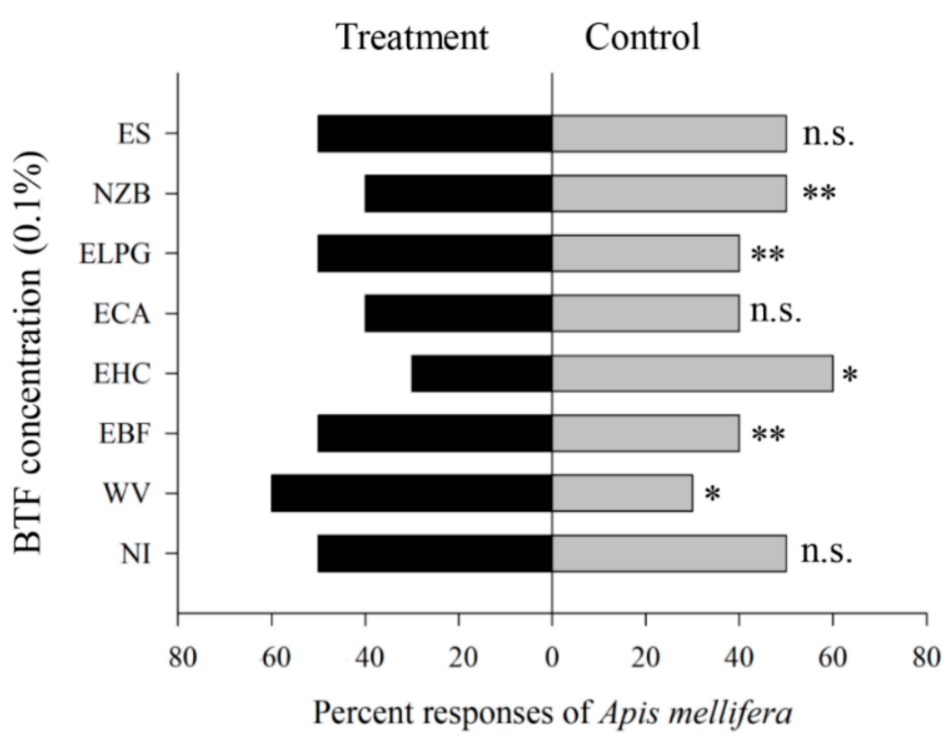

Figure 3. Olfactory responses of Apis mellifera to odors of various BTF ( $0.1 \%)$ components versus clean air in a Y-tube olfactometer. Ten adult worker bees were tested for each BTF component. Asterisks indicate significant differences: ${ }^{*} p<0.05$ and ${ }^{* *} p<0.01$ (Fisher's exact test). "n.s." indicates no significant difference between the treatment and control ( $p>0.05$; Fisher's exact test). ES, extract of seaweed; NZB, nitrogen, zinc, boron; ELPG, extract of low quality fresh Panax ginseng; ECA, extract of Chenopodium ambrosioides; EHC, extract of Houttuynia cordata; EBF, extract of Bupleurum falcatum; WV, wood vinegar; NI, inert ingredient.

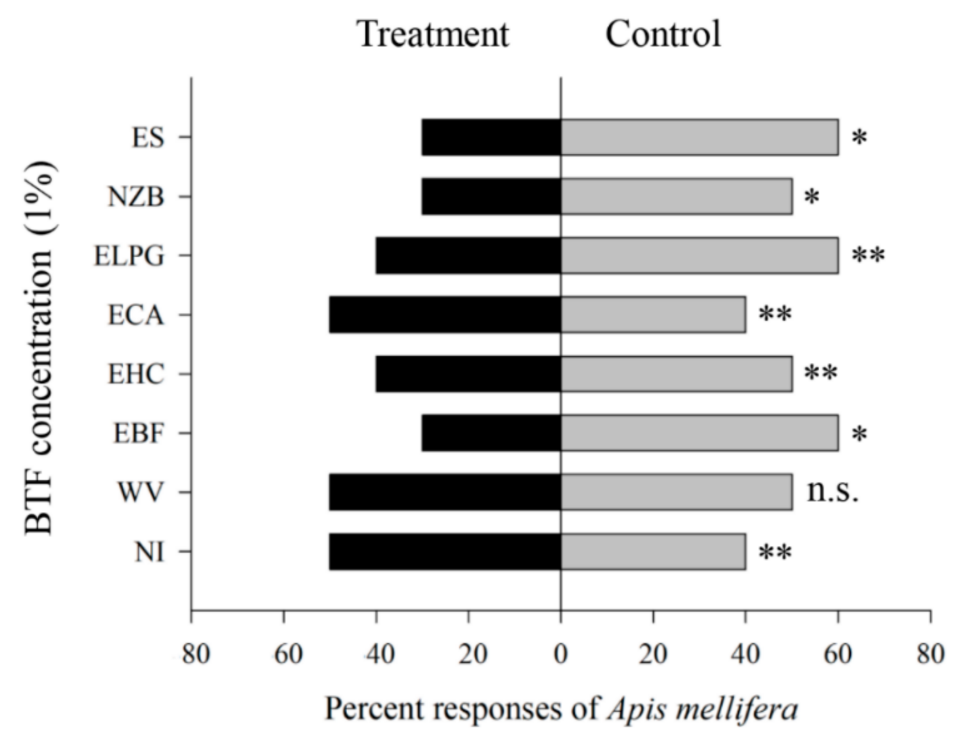

Figure 4. Olfactory responses of Apis mellifera to odors of various BTF components (1.0\%) versus clean air in a Y-tube olfactometer. Ten adult worker bees were tested for each component of BTF. Asterisks indicate significant differences: ${ }^{*} p<0.05$ and ${ }^{* *} p<0.01$ (Fisher's exact test). "n.s." indicates no significant difference between the treatment and control ( $p>0.05$; Fisher's exact test). ES, extract of seaweed; NZB, nitrogen, zinc, boron; ELPG, extract of low quality fresh Panax ginseng; ECA, extract of Chenopodium ambrosioides; EHC, extract of Houttuynia cordata; EBF, extract of Bupleurum falcatum; WV, wood vinegar; NI, inert ingredient.

The highest percent responses of $A$. mellifera at $0.1 \%$ concentration of wood vinegar (WV) $(60 \%)$ was higher than the control, and there was a significant difference $(p=0.0119$; Fisher's exact test) (Figure 3).

Only $30 \%$ of the honey bees chose the $1 \%$ concentration of the extract of seaweed (ES) and the extract of $B$. falcatum (EBF) compared with the control, and significant differences 
were observed between the treatment and control arms ( $p=0.0119$; Fisher's exact test) (Figure 4).

\section{Discussion}

To develop an eco-friendly bloom thinning agent, we developed a new BTF using minerals and extracts of seaweed and medicinal plants. The study results showed that the $0.1 \%$ BTF solution sprayed on mango trees during the blooming season reduced the total number of fruits per tree but increased the size of fruit compared with the untreated control. The BTF spray increased the fruit weight to almost two times $(196.8 \%)$ compared with the control trees at harvest time. Our result showed that the bloom thinning efficacy of BTF is remarkable for improving the size of mango fruit. The market price of mango fruit is highly dependent on the size of fruits [21]. Our study results showed that BTF treatment increased the total revenue per tree by more than two times. Hence, thinning is an important procedure to increase the market value of mango fruit.

Our BTF contains extracts of seaweeds and various medicinal plants. These plant extracts contain bioactive compounds that affect the growth, reproduction, and fruit quality of fruit trees. Studies have suggested that seaweed extracts contain several compounds that can influence the physiological characteristics of the plants, such as vegetative growth, fruit quality, and blooming [28-30]. For example, seaweed extract treatment enhances leaf chlorophyll levels [31], growth, the endogenous cytokinin content of Phaseolus vulgaris [32], and the yield of tomato plants [33]. Although studies on the bloom thinning effect of seaweed extracts are limited, our previous study on apple trees showed that the seaweed extract is effective on the bloom thinning activity [34]. Among several compounds in the seaweed extract, alginate is one of the major components. Alginate is an anionic polymer with cross-linking properties and can be used for many biomedical applications [35]. It can promote plant growth and defense by coating plant roots and seeds [36,37]. Our BTF contains $18 \%$ of seaweed extract. It would be interesting to investigate the role of a bioactive compound, such as alginate, on the bloom thinning process of fruit trees in the future.

Medicinal plants contain various bioactive compounds that exhibit pharmacological effects on humans and animals as well as antioxidant and immune effects in plants. Our BTF contained extracts of Korean ginseng Panax ginseng (Apiales: Araliaceae), Chenopodium ambrosioides (Caryophyllales: Amaranthaceae), Houttuynia cordata (Piperales: Saururaceae), and Bupleurum falcatum (Apiales: Apiaceae). These plant extracts contain various bioactive compounds, such as glycosides, polysaccharides, amino acids, flavonoids, terpenoids, and minerals [38-41]. Regarding which components of BTF act on the bloom thinning process of mango trees, our results suggest that certain bioactive compounds or a combination of these extracts stimulate the bloom thinning activity of mango trees. We hypothesized that the BTF treatment might allow early bloomed flowers to accelerate fruit setting, which induced rapid fruit growth. This phenomenon may induce more nutrient supply in the fruits than fruits that set late. The nutritional deficiency of fruits that set late result in a loss of vitality and induce physiological fruit drop of late-bloomed flowers. Further studies are necessary to identify the compounds that thin out blossoms or fruits as well as their mode of action on the thinning process in mango trees.

The timing of the thinning agent treatment coincides with the active time of insect pollinators, which are actively foraging flowers in the blooming season [1]. The present study demonstrated BTF extract's lack of influence on the olfactory behavior of honey bees. The results of Y-olfactometer analysis showed that there were no clear behavioral changes (attraction or repulsion) of worker honey bees with respect to each component of the developed BTF. Although the honey bees respond to the different concentrations of BTF but spent a similar amount of time in the Y-tube. This result suggests that our BTF can be used in the blooming season without any behavioral effects on insect pollinators. 


\section{Conclusions}

The spray of a newly developed eco-friendly BTF revealed superior thinning efficacy by inducing a reduced number but larger mango fruits. In addition, the Y-tube olfactometer experiment showed that BTF did not change the olfactory behavior of $A$. mellifera, a major insect pollinator. These results suggest that the newly developed BTF can be applied in mango orchards without disturbing honey bee behavior.

Author Contributions: Conceptualization: T.-K.S. and K.-Y.L.; methodology: T.-K.S., M.M.M., H.S.H., N.T.T. and K.-Y.L.; software: M.M.M.; formal analysis: M.M.M.; investigation: T.-K.S. and K.-Y.L.; resources: T.-K.S. and K.-Y.L.; data curation: T.-K.S. and K.-Y.L.; writing-original draft preparation: T.-K.S., M.M.M. and K.-Y.L.; writing—review and editing: T.-K.S., M.M.M. and K.-Y.L.; supervision: K.-Y.L.; project administration: K.-Y.L.; funding acquisition: T.-K.S. All authors have read and agreed to the published version of the manuscript.

Funding: This work was supported under the 2019 Technology Development Program (S2781796) and funded by the Ministry of SMEs and Startups of Korea.

Institutional Review Board Statement: Not applicable.

Informed Consent Statement: Not applicable.

Data Availability Statement: There is no supplementary information to reveal; all information is contained in this manuscript.

Acknowledgments: The authors would like to thank Enago for the English language review.

Conflicts of Interest: The authors declare no conflict of interest.

\section{References}

1. Dennis, F.G.J. The history of fruit thinning. Plant Growth Reg. 2000, 31, 1-16. [CrossRef]

2. Costa, G.; Vizzotto, G. Fruit thinning of peach trees. Plant Growth Reg. 2000, 31, 113-119. [CrossRef]

3. Coneva, E.D.; Cline, J.A. Blossom thinners reduce crop load and increase fruit size and quality of peaches. HortScience 2006, 41, 1253-1258. [CrossRef]

4. Kon, T.M.; Schupp, J.R. Apple crop load management with special focus on early thinning strategies: A US perspective. Hortic. Rev. 2019, 46, 255-298.

5. Costa, G. Two decades of activity of the "Fruit Chemical Thinning" working group of the EUFRIN network. Acta Hortic. 2016, 1138, 1-7. [CrossRef]

6. Martin-Gorriz, B.; Torregrosa, A.; García Brunton, J. Post-bloom mechanical thinning for can peaches using a hand-held electrical device. Sci. Hortic. 2012, 144, 179-186. [CrossRef]

7. Wertheim, S.J. Developments in the chemical thinning of apple and pear. Plant Growth Reg. 2000, 31, 85-100. [CrossRef]

8. Jones, K.M.; Koen, T.B.; Meredith, R.J. Thinning 'Golden Delicious' apples using ethephon sprays. J. Hort. Sci. 1983, 58, 381-388. [CrossRef]

9. Nielsen, J.C.; Dennis, F.G. Thinning 'Delicious' apples; trials and tribulations. J. Hort. Sci. 1983, $28,484$.

10. Jemric, T.; Pavicic, N.; Blaskovic, D.; Krapac, M.; Pavicic, D. The effect of hand and chemical fruit thinning on 'Golden Delicious cl. B' apple fruit quality. Curr. Stud. Biotech. 2003, 3, 193-198.

11. Matta, F.B.; Ouma, G. Apple cultivar responses to fruit thinning Agents accel and carbaryl in northern Mississippi. Bull. Mafes 2007, 1161, 1-9.

12. Berlanga Reyes, D.I.; Romo Chacon, A.; Martinez Campos, A.R.; Guerrero Prieto, V.M. Apple fruit chemical thinning in Chihuahua, Mexico. Rev. Fitotec. Mex. 2008, 31, 243-250.

13. Greene, D.; Costa, G. Fruit thinning in pome-and stone-fruit: State of the art. Acta Hortic. 2013, 998, 93-102. [CrossRef]

14. Lenahan, O.M.; Whiting, M.D. Fish oil plus lime sulfur shows potential as a sweet cherry postbloom thinning agent. HortScience 2006, 41, 860-861. [CrossRef]

15. Schoedl, K.; Denk, A.; Hummelbrunner, S.; Modl, P.; Forneck, A. No improvement in fruit quality through chemical bloom thinning in sweet cherry (Prunus avium L.). J. Sci. Food Agric. 2009, 89, 1236-1240. [CrossRef]

16. Batjer, L.P.; Westwood, M.N. 1-Naphthyl n-methylcarbamate, a new chemical for thinning apples. Proc. Am. Soc. Hort. Sci. 1960, 75, 1-4.

17. Williams, M.W. Sulfcarbamide, a blossom-Thinning agent for apples. Hort Technol. 1993, 3, 322-324. [CrossRef]

18. Jahan, S.M.H.; Shim, J.-K.; Son, T.-K.; Jo, J.; Choi, C.; Lee, K.-Y. Effects of bloom thinning formulation on activities of digestive enzymes and acetylcholinesterase in honeybee Apis mellifera. Curr. Res. Agric. Life Sci. 2014, 32, 63-66. [CrossRef]

19. Peck, G.M.; Combs, L.D.; DeLong, C.; Yoder, K.S. Precision apple bloom thinning using organically approved chemicals. Acta Hortic. 2016, 1137, 47-52. [CrossRef] 
20. Son, T.-K.; Hwang, H.-S.; Mostafiz, M.M.; Ozaki, Y.; Lee, K.-Y. Effects of eco-friendly bloom thinning formulations on a pollination insect, Apis mellifera. J. Fac. Agric. Kyushu Univ. 2020, 65, 233-236. [CrossRef]

21. Tharanathan, R.N.; Yashoda, H.M.; Prabha, T.N. Mango (Mangifera indica L.), “The King of Fruits"—An Overview. Food Rev. Int. 2006, 22, 95-123. [CrossRef]

22. Jackson, J.E. The manipulation of fruiting. In The Manipulation of Fruiting; Wright, C.J., Ed.; Butterworth \& Co.: London, UK, 1989.

23. Sasaki, K.; Utsunomiya, N. Effect of fruit thinning on fruit growth and profitability in 'Irwin' mango cultivation under greenhouse. Jpn. J. Trop. Agric. 2002, 46, 295-297.

24. Yeshitela, T.; Robbertse, P.J.; Fivas, J. Effects of fruit thinning on 'Senation' mango (Mangifera indica) trees with respect to fruit quantity, quality and tree phenology. Expl. Agric. 2004, 40, 433-444. [CrossRef]

25. Mostafiz, M.M.; Hassan, E.; Shim, J.-K.; Lee, K.-Y. Lethal and sublethal effects of methyl benzoate on the predatory bug Nesidiocoris tenuis. Insects 2020, 11, 377. [CrossRef]

26. Li, Y.; Zhong, S.; Qin, Y.; Zhang, S.; Gao, Z.; Dang, Z.; Pan, W. Identification of plant chemicals attracting and repelling whiteflies. Arthropod Plant Interact. 2014, 8, 183-190. [CrossRef]

27. SAS. SAS Institute Inc Base SAS 9.4 Procedures Guide: High-Performance Procedures, 6th ed.; SAS Institute 390 Inc.: Cary, NC, USA, 2016.

28. Khan, W.; Rayirath, U.P.; Subramanian, S.; Jithesh, M.N.; Rayorath, P.; Hodges, D.M.; Critchley, A.T.; Craigie, J.S.; Norrie, J.; Prithiviraj, B. Seaweed extracts as biostimulants of plant growth and development. J. Plant Growth Regul. 2009, 28, 386-399. [CrossRef]

29. Colla, G.; Cardarelli, M.; Bonini, P.; Rouphael, Y. Foliar applications of protein hydrolysate, plant and seaweed extracts increase yield but differentially modulate fruit quality of greenhouse tomato. HortiScience 2017, 52, 1214-1220. [CrossRef]

30. Polo, J.; Mata, P. Evaluation of a biostimulant (Pepton) based in enzymatic hydrolyzed animal protein in comparison to seaweed extracts on root development, vegetative growth, blooming, and yield of gold cherry tomatoes grown under low stress ambient field conditions. Front. Plant Sci. 2018, 8, 2261. [CrossRef]

31. Blunden, G.; Jenkins, T.; Liu, Y. Enhanced leaf chlorophyll levels in plants treated with seaweed extract. J. Appl. Phycol. 1997, 8, 535-543. [CrossRef]

32. Featonby-Smith, B.C.; Van Staden, J. The effect of seaweed concentrates and fertilizer on growth and the endogenous cytokinin content of Phaseolus vulgaris. S. Afr. J. Bot. 1984, 3, 375-379. [CrossRef]

33. Crouch, I.J.; Van Staden, J. Effect of seaweed concentrate on the establishment and yield of greenhouse tomato plants. J. Appl. Phycol. 1992, 4, 291-296. [CrossRef]

34. Son, T.-K.; Ozaki, Y.; Lee, K.-Y. A study on labor force reduction and fruit quality with the use of substances showing thinning effect in 'Fuji' and 'Arisu' apple varieties. J. Fac. Agric. Kyushu Univ. 2020, 65, 257-261. [CrossRef]

35. Lee, K.-Y.; Mooney, D.J. Alginate: Properties and biomedical applications. Prog. Polm. Sci. 2012, 37, 106-126. [CrossRef]

36. Sarrocco, S.; Raeta, R.; Vannacci, G. Seeds encapsulation in calcium alginate pellets. Seed Sci. Tech. 2004, 32, 649-661. [CrossRef]

37. Faisal, M.; Anis, M. Regeneration of plants from alginate-encapsulated shoots of Tylophora indica (Burm. f.) Merrill, an endangered medicinal plant. J. Horti. Sci. Biotech. 2007, 82, 351-354. [CrossRef]

38. Shibata, S. Chemistry of components in ginseng. J. Tradit. Sino Jpn. Med. 1982, 3, 62-69.

39. Chou, S.C.; Su, C.R.; Ku, Y.C.; Wu, T.S. The constituents and their bioactivities of Houttuynia cordata. Chem. Pharm. Bull. 2009, 57, 1227-1230. [CrossRef] [PubMed]

40. Christensen, L.P. Ginsenosides chemistry, biosynthesis, analysis, and potential health effects. Adv. Food Nutr. Res. 2009, 55, 1-99. [PubMed]

41. Reyes-Becerril, M.; Angulo, C.; Sanchez, V.; Vázquez-Martínez, J.; López, M.G. Antioxidant, intestinal immune status and anti-inflammatory potential of Chenopodium ambrosioides L. in fish: In vitro and in vivo studies. Fish Shellfish. Immunol. 2019, 86, 420-428. [CrossRef] 